\title{
Sustainability in projects: an analysis of relevant sustainability aspects in the project management process based on the three pillars model
}

\author{
S. Kirchhof ${ }^{1} \&$ R. Brandtweiner ${ }^{2}$ \\ ${ }^{1}$ University of Applied Sciences BFI Vienna, Austria \\ ${ }^{2}$ Vienna University of Economics and Business, Austria
}

\begin{abstract}
Project management and sustainability are two concepts which increase in popularity constantly. The concept of sustainability has to be integrated throughout a company and therefore has to be considered during the whole process of project management. In order to anchor the concept of sustainability in a project it is necessary to focus on ecological, social and economic aspects. The creation and implementation of such an integrated management approach will lead to the creation of additional value for companies. This paper discusses the potential of incorporating sustainability in project management.

Keywords: project management, corporate social responsibility, sustainability concepts.
\end{abstract}

\section{Introduction}

The concept of sustainability and corresponding discussions has existed for a fairly long time. Greater interest in this topic has arisen in society through the higher attention paid to sustainability by the mass media. Global warming, natural disasters and constantly increasing poverty all across the world have led even in the well-developed and industrialised countries to thoughts about the cross-generational, long-term and responsible use of resources. In addition, the world depression induced by the disproportional allocation of financial resources highlights the urgency of incorporating the sustainability concept in all economic activities. Companies have to focus on sustainable management. Furthermore, 
they have to ensure that their business practices generate not only company, but social value as well. The aim of this paper is to analyse how companies can ensure sustainability in their organisation and how the concept is included in the project management process.

To evaluate and to complement the theoretical analysis, qualitative expert interviews were conducted with project managers from companies in the Austrian telecommunication and information technology industry.

The following research question constitutes the basis of this paper:

Which dimensions of sustainability can be identified in the project management process, especially in the planning phase of the project?

Further following sub questions were derived:

- Does a clear reference to sustainability in the mission statement lead to the incorporation of sustainability in the project management process?

- Which specific concepts and methods are used for the integration of sustainability in project management?

- What role does the project manager play in this process?

The empirical study focuses on the three pillars of sustainability: economy, environment and society. The factors of long-term orientation, and the usage of traditional management and project-management tools to ensure the incorporation of sustainability aspects in the project management process were also considered. The expert interviews were structured to collect data relating to the different project management phases of initiating, planning, executing, monitoring and controlling, and closing [1].

\section{Theoretical foundation}

\subsection{Sustainability}

Economic activities are regarded as sustainable when they are conducted with a long-term focus, i.e. when they have positive influences on the company over a long period of time. Sustainability is defined as "[...] development that meets the needs of the present without compromising the ability of future generations to meet their own needs" [2]. The idea of sustainability goes back to the $17^{\text {th }}$ century where it was used in forestry to ensure a replenished supply of wood. The basic idea of the concept was to deforest only that amount of wood which could grow back naturally. In the $20^{\text {th }}$ century it was realised that environmental problems are always linked with the economy and with the society as well. Numerous international conferences have been discussing the sustainability approach for decades in order to establish global consensus about which procedures should be established to deal with the current problems caused by the over-exploitation of both environment and society. Although the discussion goes back over 40 years a general agreement and specific procedures have not yet been found. It is theorised that parties try to enforce their individual interests and focus primarily on their own objectives $[3,4]$. 


\subsection{Projects and project management}

Many companies use projects to fulfil their business activities. A project can be defined as a temporary, complex, relatively new, resource intensive, interdisciplinary and risky undertaking. Project management is described as the management discipline of planning and controlling projects during their progress. Although projects are by definition of a temporary nature, and sustainability is always orientated to the long-term, a linkage between the two concepts exists: e.g. realised projects may have influences on a company's long term, i.e. strategic, goals [5].

\subsection{Concepts and tools}

To explain sustainability different concepts have been developed, the three pillar model is the most popular one.

\subsubsection{Three pillars of sustainability}

A basic concept which builds the foundation of the discussion is the model of the "three pillars of sustainability". In the literature we find single- and multi-pillar models. Single pillar models focus on the environmental aspects of sustainability. Multi-pillar models, like the "three pillars of sustainability", focus on ecological, economical and social aspects. The three dimensions of the model should be considered equally. If one dimension is disregarded impacts for the other dimensions could occur. The "three pillars model" is used as the basis for our investigation. Through the integrated view of this model different aspects which influence or are influenced by the company are taken into account.

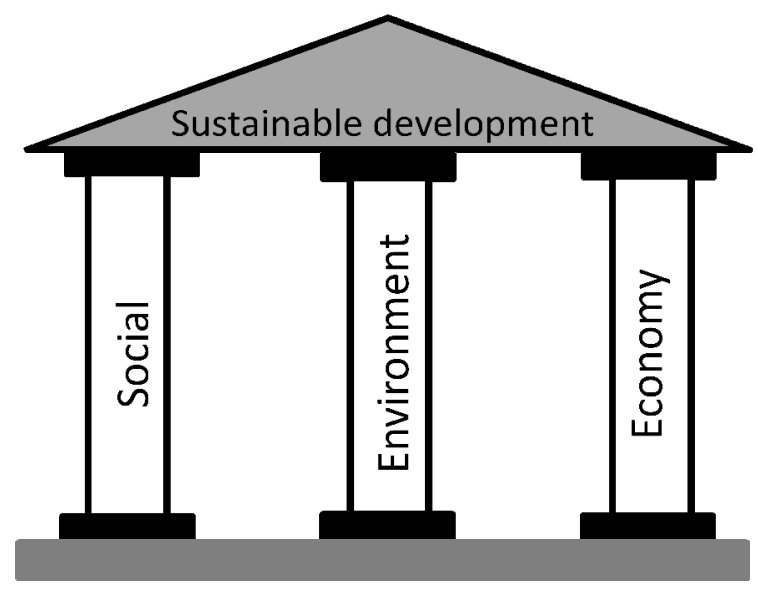

Figure 1: $\quad$ The three pillars of sustainability [8].

\subsubsection{Corporate social responsibility}

Corporate social responsibility (CSR) and sustainable management are two fairly similar concepts. While CSR was developed from a socially-focused perspective, 
sustainability was developed from the ecological point of view [6]. Both theories try to incorporate the notations of sustainable thinking in managerial activities. According to the European Commission sustainable management is the broader one [7].

\subsubsection{Tools}

If a company decides to establish sustainability, it is essential to communicate the corresponding actions and make them transparent to the company's environment. Relevant interest groups have to be informed. Sustainability reports are one method used to communicate and measure sustainability. International guidelines have been issued in order to make their use comparable. An institution which provides such guidelines is the Global Reporting Initiative (GRI). More detailed information as to the implemented procedures could be provided directly to the interested stakeholders [3, 4].

Another tool to identify specific sustainability dimensions and develop appropriate strategies to achieve the corresponding targets is the sustainability balanced scorecard. The sustainability balanced scorecard is based on the traditional balanced scorecard and the integration of the sustainability dimension can be conducted in several ways. The concrete form of integrating sustainability in the balanced scorecard depends on the individual key aspects of a company [9]. Another method of measuring sustainability is sustainability ratings. In contrast to conventional ratings, which concentrate on financial key figures, the sustainability ratings also focus on social and ecological factors. Companies with extraordinarily good ratings points could be affiliated in sustainability stock indices [10]. In addition, companies could undergo sustainability audits. The audits offer the opportunity to identify both synergies and conflicting sustainability goals. The aim of the audit is to determine the actual progress of the company's efforts to become a sustainable company. Furthermore necessary changes and suitable measures are identified [3]. Through sustainability audits, companies have the possibility to acquire certificates which attest to implemented actions.

\section{Sustainability and project management in companies}

The basic step to integrate sustainability in the company is to embed the concept of sustainability in the company's strategy and its vision and mission statement. The reasons for companies to integrate the sustainability concept are diverse. A major reason is that organisations which show a long-term orientation in their managerial activities have higher chances of survival in periods of crisis [11]. If companies realise that sustainable management creates strategic market advantages, their business portfolio can be extended and innovations regarding the principles of sustainable management can be promoted [12]. Other advantages arising from sustainable strategies are the attraction of new costumers, increased profitability and therefore increased shareholder value [13]. 


\section{Empirical findings concerning the integration of sustainability in the project management process}

The expert interviews undertaken have shown that the relevance of sustainability to project management is assessed as very important. The basis of sustainable management is the integration of the concept in the guiding principles and the strategy of the company. Companies define strategies and use projects to implement the evaluated strategies. Classical strategy definition and implementation with classical management tools like SWOT Analysis or Portfolio-Analysis can improve the process of strategy formulation and ensure the implementation of the sustainability aspect in the vision and mission statement of a company. Additionally, every employee is regarded as responsible for rooting the sustainability principles in the organisation.

\subsection{Business as usual: integrating economic aspects}

Regularly, in the opening stages of a project, economic factors are primarily taken into account. Project planning is considered to be long-term oriented and the planning period normally exceeds the project end, with standardised tools and processes ensuring the accuracy of the planning. The interviews we have carried out with practitioners have shown clearly that an explicit integration of sustainability aspects in the project definition process is not happening, as the process of defining the project is characterised by an emphasis on economic issues. Social and ecological issues are neither in the focus of project managers nor are they addressed by the board of directors. Nevertheless the interviewees stated that incorporating sustainability in the definition phase should be very important. Despite these statements the interviews show that the planning of resources, especially bottleneck resources, happens beforehand and long-term impacts are taken into account. If a project appears to be negative, in terms of financial statements, it will be stopped or will be re-planned.

\subsection{Integrating ecological aspects}

The interviews have shown that the integration of ecological aspects is not very common in the project management process. In contrast to the consideration of profit oriented aspects, any negative environmental impacts of a project would not normally be regarded. The interviewees stated that normally, environmental aspects are taken into account by the board of directors in a more general way, i.e. they try to ensure that certificates and awards are gained in order to ensure, from a PR point of view, an improvement in the reputation of the company. Furthermore the interviews have shown that environmental aspects get more attention in pragmatic and operative areas such as facility management, e.g. by measures that ensure the saving of electricity.

If costs which could arise because of disregarding the environmental impacts of projects were then assessed by applying tools of risk management, the findings could be included in the project's budget. Nevertheless the interviewees 
pointed out that, from a theoretical project management point of view, practically all environmental aspects could be easily integrated in project management. One way of doing this would be the observation of the innovation process and the theory-based investigation and assessment of the whole life-cycle of a specific product or service.

\subsection{Integrating social aspects}

The active participation of employees was regarded as very important by the interviewees. Therefore they suggested that management concepts such as management by objectives should be used to increase the involvement of employees in sustainable project management. Furthermore it was suggested that the social environment of the project should be continuously and actively included in project management. Stakeholder analysis and consolidation meetings with different stakeholder groups, as well as regular reports, are important and powerful tools to communicate the company's commitment to sustainable management to different stakeholder groups.

\subsection{Long-term orientation}

The aspect of long-term orientation is provided through management tools and methods which provide standards and give guidance to fulfil classical managerial requirements. Furthermore, the interviewed experts addressed the fact that normally "projects are planned over the project end"; i.e. the majority of projects are long-term oriented, at least in means of profitability and economic sustainability.

\subsection{Tools and methods}

To integrate sustainability and ensure efficient project management, standardised project management tools, as for example defined by the European IPMA (International Project Management Association) or the US-American PMI (Project Management Institute), are used. The usage of specific project management methods is voluntary. Some companies adopt rules which make the usage of certain tools and/or standards (either IPMA or PMI) obligatory. The vast majority of the interviewees stated that the control of the usage of these standards has to be optimised.

The interviewed experts identified risk management as an important approach for ensuring sustainability in project management. Employing the instruments of risk management makes sure that risks could be identified earlier and suitable solutions could be found more easily. This might lead to a long-term, efficient and problem-free execution of a project.

Furthermore, strategic management and financial planning, quality management, knowledge management and product management were mentioned by the interviewees as useful approaches to ensure sustainability in project management. 
In the closing phase of projects, methods for the exchange of experiences are used to ensure knowledge transfer in order to ensure a long-term success of the project. In addition, systems like knowledge management databases are used, to conserve information and derive profits from already realised projects. Project managers have to ensure that the data collected is available for all project members and can be accessed easily. Knowledge management and the exchange of experiences are significant critical success factors which influence the longterm impact of projects and therefore the development of the company.

The incorporation of Corporate Social Responsibility concepts could be found in varying forms in different companies. The interviewees stated that the incorporation of CSR concepts correlates positively to the size of the companies, i.e. the bigger the company, the more likely is the implementation of CSR concepts.

Furthermore, the study shows that ecology certificates are also primarily of interest for larger companies. Participation in sustainability ratings or a quotation in a sustainability stock index are not yet established within Austrian telecommunication and information technology industries. Likewise the level of awareness of sustainability tools, such as the sustainability balanced scorecard, is not very high. However classical tools like the project scorecard or the traditional balanced scorecard are popular and are widely in use.

\section{Summary and concluding remarks}

The empirical findings revealed that the sustainability concept is more than a passing fad. Sustainability, long-term added value, and a balanced relationship to the natural and social environment of the company are critical success factors for a long-lasting and prospering business. Due to the fact that using projects for fulfilling organisational tasks is a wide spread management practice, the sustainability concept has to be integrated on the project management level as well.

The interviews have shown that nowadays in project management, especially in the planning phase, the economic pillar of the sustainability concept is overemphasized compared to the two other sustainability dimensions. The project mangers revealed that social aspects are regarded as relatively important too, but those aspects have been clearly placed in second place behind the economic aspects, while environmental factors are seen as the least important.

Projects are social systems and react to environmental influences. This means that a basic prerequisite for incorporating sustainability in the project management process is the inclusion of the concept in the company's strategy and culture. Concepts which have been established at a general company level influence all of the company's management processes. Therefore, the integration of the sustainability concept has to be supported and enforced by the whole organisation.

During every day's work, project managers have to ensure that each member of a project team is acting in accordance with the established sustainability principles as much as it is their obligation to ensure that the results of projects 
create sustainable value. The inclusion of social aspects in the project management process could be realised by e.g. employing knowledge management tools which may also lead to higher and/or more active participation of employees, which regularly enhances a company's innovation capabilities.

Sustainability reports were explicitly named by the interviewees as a suitable way to point out the degree of sustainability in a company's procedures and make it visible to the stakeholders of the company. In effect, the reports are seen as very useful for creating transparency. Additionally our empirical analysis has shown that well known instruments such as the sustainability balanced scorecard, sustainability ratings and audits are not often used, i.e. they have to be reintroduced more effectively. Principally these concepts are well known, but not used in business practice. Project managers themselves stated that companies have to be convinced to make more intensive use of these instruments in future.

These project managers believe that the holistic concept of sustainability will become more and more important for all industries. Therefore its importance for project management in general will increase too.

\section{References}

[1] PMBOK Guide, A Guide to Project Management Body of Knowledge, Project Management Institute, Four Campus Boulevard, Newton Square, 2000

[2] United Nations, Our Common Future (1987), Chapter 2: Towards Sustainable Development, http://www.undocuments.net/ocf-02.htm\#I, 2010

[3] Promberger K., Spiess H., Kössler W., Unternehmen und Nachhaltigkeit Eine managementorientierte Einführung in die Grundlagen nachhaltigen Wirtschaftens, Linde Verlag, 2006

[4] Brundtland Report, in: Lexikon der Nachhaltigkeit, http://www.nachhaltigkeit.info/artikel/brundtland_report_1987_728.htm, 2010

[5] Jankulik E., Kuhlang P., Piff R., Projektmanagement und Prozessmessung die Balanced Scorecard im projektorientierten Unternehmen, Publics Corporate Publishing Erlangen, 2005

[6] Meffert H., Müstermann M., Corporate Social Responsibility in Wissenschaft und Praxis, Meffert H., Backhaus K., Becker J. (Hrsg.) Wissenschaftliche Gesellschaft für Marketing und Unternehmensführung e.V., Arbeitspapier Nr. 186, 2005

[7] European Commission, Nachhaltiges und verantwortungsbewusstes Unternehmertum - Soziale Verantwortung der Unternehmen (CSR), http://ec.europa.eu/enterprise/policies/sustainablebusiness/corporate-socialresponsibility/index_de.htm, 2010

[8] Sustainability-Ed: What is sustainable development, http://www.sustainability-ed.org.uk/pages/what3-1.htm 
[9] Waniczek M., Werderits E., Sustainability Balanced Scorecard Nachhaltigkeit in der Praxis erfolgreich managen - mit umfangreichem Fallbeispiel, Linde Verlag, 2006

[10] Sustainable Investment, Indizes, abrufbar unter URL: http://www.nachhaltiges-investment.org/Indizes.aspx, 2010

[11] Wilson M. in Pricewaterhouse Coopers, Communications Review Volume 12, No. 1, 2007 http://www.pwc.de/portal/pub/!ut/p/c4/ 04_SB8K8xLLM9MSSzPy8xBz9CP0os3gDA2NPz5DgAF9nA0dPN3M_F 0tnAwjQL8h2VAQAtmMS_w!!/?topNavNode=49c411a4006ba50c\&site $\bar{A}$ rea $=49$ ceac14e70252ea\&content $=$ e5f936094441a7b

[12] Strigl A., Resel K., Kanatschnik D., Warum sich Unternehmen mit Nachhaltigkeit beschäftigen sollten?, 2003, http://oin.boku.ac.at/ oin/_artikel/nachhaltigkeit_in_unternehmen.pdf

[13] The Economist Intelligence Unit, Doing Good - Business and the sustainability challenge, The economist, http://www.niri.org/OtherContent/Doing-Good-Business-the-Sustainability-Challenge-EconomistIntelligence-Unit.aspx, 43:48, 2008 